\title{
Field inoculation of arbuscular mycorrhiza on maize (Zea mays L.) under low inputs: preliminary study on quantitative and qualitative aspects
}

\author{
Emilio Sabia, ${ }^{1}$ Salvatore Claps, ${ }^{1}$ Giuseppe Morone, ${ }^{1}$ Annarita Bruno, ${ }^{1}$ Lucia Sepe, ${ }^{1}$ \\ Riccardo Aleandri ${ }^{2}$ \\ ${ }^{1}$ Consiglio per la ricerca in agricoltura e l'analisi dell'economia agraria, Unità di Ricerca per \\ la Zootecnia Estensiva, Muro Lucano (PZ); ${ }^{2}$ Consiglio per la ricerca in agricoltura e l'analisi \\ dell'economia agraria, Dipartimento di Biologia e Produzioni Animali, Roma, Italy
}

\begin{abstract}
Arbuscular mycorrhizal symbiosis contributes to the sustainability of soil-plant system. A field experiment was conducted to examine the effect of arbuscular mycorrhiza (AM) on quantitative and qualitative performance in forage maize (Zea mays L). Within the project Sviluppo di modelli zootecnici ai fini della sostenibilità (SOS-ZOOT) a trial was conducted at the experimental farm of the Agricultural Research Council in Bella (PZ), located in Basilicata region (Southern Italy) at $360 \mathrm{~m}$ asl, characterised by an annual rainfall of approximately $650 \mathrm{~mm}$. For spring sowing, two plots of $2500 \mathrm{~m}^{2}$ were used, one sown with seeds inoculated with AM (M), $1.0 \mathrm{~kg} / \mathrm{ha}$, and the other one with non-inoculated seeds (NM). After 120 days after sowing, when plants showed 30\% dry matter, five replicates of $1 \mathrm{~m}^{2}$ per plot were used to estimate dry matter yield (DMY), while half plot was dedicated to the assessment of grain production. For each replicate, three representative plants were consid-
\end{abstract}

Correspondence: Emilio Sabia, via Appia, Bella Scalo, 85054 Muro Lucano (PZ), Italy.

Tel: +39.0976.72915. E-mail: emilio.sabia@entecra.it

Key words: Glomus spp., maize forage, quality production, plant phosphorus, sustainability agriculture.

Conference presentation: Meeting on Environmental Sustainability and Food Security, Potenza, Italy, 2014.

Acknowledgments: the authors thank G. Caternolo for its expert technical assistance.

Funding: this research was funded by the Italian Ministry of Agricultural, Food, Forestry Policies (MiPAAF); project Sviluppo di modelli zootecnici ai fini della sostenibilità (SOS-ZOOT).

Received for publication: 23 June 2014.

Revision received: 22 January 2015.

Accepted for publication: 29 January 2015.

(C) Copyright E. Sabia et al., 2015

Licensee PAGEPress, Italy

Italian Journal of Agronomy 2015; 10:607

doi:10.4081/ija.2015.607

This article is distributed under the terms of the Creative Commons Attribution Noncommercial License (by-nc 3.0) which permits any noncommercial use, distribution, and reproduction in any medium, provided the original author(s) and source are credited. ered; each plant was measured for height and was divided into leaves, stem and ear. For each plot, the following constituents were determined: crude protein, ash, ether extract, crude fibre (CF), fractions of fibre [neutral detergent (NDF), acid detergent fibre (ADF) and sulphuric acid lignin] and phosphorus (P). Throughout the period of plants' growth, no herbicides, organic or inorganic fertilisation, and irrigation water were distributed. The preliminary results revealed a significant effect of AM inoculation on forage maize DMY, P content in the whole plant, into the leaves and on the quality of steam. The $M$ thesis showed a significant increase in terms of DMY in comparison with the NM thesis: $21.2 \mathrm{vs} 17.9$ t/ha $(\mathrm{P}<0.05)$. The mycorrhized whole plants $[0.22$ vs $0.17 \%$ dry matter (DM), $\mathrm{P}<0.05]$ and leaves $(0.14$ vs $0.09 \% \mathrm{DM}, \mathrm{P}<0.05)$ showed an increased $\mathrm{P}$ content. The stems of $\mathrm{M}$ plants showed a content of $\mathrm{CF}, \mathrm{NDF}$, ADF and Ash significantly lower compared with NM plants. No significant differences were observed for the other parameters. The preliminary study revealed a significant effect of AM seed inoculation on DMY and quality of forage maize cultivated within a low input system.

\section{Introduction}

Arbuscular mycorrhizal (AM) fungi form a ubiquitous symbiotic relationship with over $90 \%$ of land plants (Smith and Read, 1997). AM can directly and indirectly influence soil microbial communities (Rilling, 2004). The symbiotic relationship between AM and the roots of higher plants contributes significantly to plant nutrition and growth and has been shown to increase the productivity of a variety of agronomic crops including maize (Augé, 2001). These positive responses in productivity to AM colonisation have mainly been attributed to the enhanced uptake by AM of relatively immobile soil ions such as phosphorus (P), potassium $(\mathrm{K})$, calcium (Ca), magnesium (Mg), sulphur, iron, zinc (Zn), copper, and manganese (Mn) (Liu et al., 2000). In maize and other species, the most widely recognized contribution of AM fungi to host-plant nutrition involves their ability to extract $P$ from outside the $P$ depletion zone around plant roots (Liu et al., 2000). Though the AM association can offer multiple benefits to the host plant it may not be obviously mutualistic at all points in time, and it is possible under some conditions that the AM may cheat their host plant into supplying carbon (C) with no apparent benefit to the plant (Gosling et al., 2006). Sabia et al. (2015) observed that inoculation with AM could increase in vivo digestibility of forages used for animal feeding. Use of other readily soluble fertilisers, particularly nitrogen $(\mathrm{N})$ fertilisers, has also been reported to have a negative impact on AM colonisation and/or diversity in some cases (Liu et al., 2000), but the effect of biocides on the AM association is complex and not easily predictable and the effect of fungicides is not straightforward. Crop management involves a range of practices which can impact on the AM association, both directly, by damaging or killing AM and indirectly, by creating conditions either favourable or unfavourable to AM 
(Gosling et al., 2006). In general, agricultural practices have a negative impact on the AM association and agricultural soils are AM impoverished, particularly in terms of numbers of species (Menèndez et al., 2001). Many farm management practices, such as use of water-soluble $P$ fertilisers and biocides are also disruptive to the AM association, resulting in AM communities which are impoverished, both in terms of numbers of individuals and species diversity (Gosling et al., 2006). However, little is known about the effect of field inoculation of AM in maize under low inputs conditions. Therefore, the present study aims to evaluate the effects on the field inoculation under low energy inputs on the quantitative and qualitative aspect in maize.

\section{Materials and methods}

The study was carried out at Agricultural Research Council (CRA), Research Unit for the Extensive Animal Husbandry located in Bella (PZ), Basilicata region, Southern Italy $\left(40^{\circ} 42^{\prime} \mathrm{N}, 15^{\circ} 32^{\prime} \mathrm{E}\right)$, characterised by an annual rainfall of approximately $650 \mathrm{~mm}$, whereas during the period of crop growth there were approximately $200 \mathrm{~mm}$ of rainfall (Stelluti, 2009). For spring sowing two plots of $2500 \mathrm{~m}^{2}$ were used; the plots were located in a land with superficial groundwater, therefore soil moisture was high throughout the experimental period. Commercial seed were used from Pioneear corn (Zea mays L.) hybrids PR32W86 and seed rate for each plots were 7 seeds per $\mathrm{m}^{2}$. Sowing was conducted on May $13^{\text {th }} 2013$. The plants were grown $70 \mathrm{~cm}$ apart between the rows with $20 \mathrm{~cm}$ spacing in each row and intervals between plots were $2 \mathrm{~m}$. One plot was sown with seeds inoculated with AM (M) were treated by Micosat $\mathrm{F}^{\circledR}$ (C.C.S. Aosta s.r.l., Quart, A0, Italy), consisting of spores, soil, hyphae and root fragments of infected clover (Trifolium repens) of AM fungus of Glomus spp. The seeds for M theses were dressed distributing the product in amount of $1.0 \mathrm{~kg} / \mathrm{ha}$, and the other one plot with non-inoculated seeds (NM). Throughout the period of plants' growth, no herbicides, organic or inorganic fertilisation, and irrigation water were distributed. The soil composition in plots was: cation exchange capacity $25.22 \mathrm{meq} / 100 \mathrm{~g}$, Ca $21.84 \mathrm{meq} / 100 \mathrm{~g}, \mathrm{Mg} 2.99 \mathrm{meq} / 100 \mathrm{~g}, \mathrm{~K}$ $0.71 \mathrm{meq} / 100 \mathrm{~g}$, sodium $0.30 \mathrm{meq} / 100 \mathrm{~g}, \mathrm{pH} 7.27, \mathrm{P}_{2} \mathrm{O}_{5} 43.58 \mathrm{ppm}$, organic C $1.69 \%$, organic matter $2.91 \%$. At harvesting 13 September 2013, 120 days after sowing, when plants showed 30\% dry matter (DM), five replicates of $1 \mathrm{~m}^{2}$ per plots were used to estimate DM yield (DMY), while half plot was dedicated to the assessment of grain production when the ear showed $80 \%$ DM. For each replicate, three representative plants were considered; each plant was measured for height and was divided into leaves, stem and ear. For whole plant, leaves, stem, ear and grain following constituent was performed: for determination of DM content, each samples were oven-dried $\left(65^{\circ} \mathrm{C}\right.$ for $\left.72 \mathrm{~h}\right)$ and afterwards ground (Cyclotec Tecator mill with a mesh grid of $1 \mathrm{~mm}$ ). The ether extract was determined by extraction with petroleum ether AOAC (1990); the ash was determined in a muffle furnace at $550^{\circ} \mathrm{C}$ for $3 \mathrm{~h} \mathrm{AOAC} \mathrm{(1990);} \mathrm{the}$ $\mathrm{N}$ content was determined by using the Kjeldhal method, those values were converted to crude protein (CP) by multiplying by a factor of 6.25 AOAC (1990); the neutral detergent (NDF) and acid detergent fibre (ADF) and sulphuric acid lignin analyses were performed by the sequential procedure of Van Soest et al. (1991), using the Ankom 200 Fiber Analyzer (ANKOM Technology Corporation, Macedon, NY, USA). The NDF was assayed with sodium sulphite and without $\alpha$-amylase, and $\mathrm{P}$ concentrations were also determined in according to AOAC (1990). All data were subjected to analysis of variance using the general linear model procedure with the treatment as fixed effect of the statistical analysis system (SAS) ver. 6 (SAS Institute, Cary, NC, USA). Significance between means was tested using Fisher's least significance difference.

\section{Results}

Total DM yield, grain production and quantitative performance of different part of plant are show in Table 1. The maize treatment with spore of AM had higher of DMY than to the NM [mean \pm standard error (SE): $21.2 \pm 1.9$ vs $17.9 \pm 1.9$ t/ha; $\mathrm{P}<0.05]$. The $\mathrm{M}$ maize plants showed a number of plants per square metre higher than to the NM (mean $\pm \mathrm{SE}$ : $5.6 \pm 0.1$ vs $4.9 \pm 0.1$ plants $/ \mathrm{m}^{2} ; \mathrm{P}<0.05$ ). Chemical composition on $\%$ of DM of whole plant and leaves are show in Tables 2 and 3, respectively. The content of $\mathrm{P}$ in $\mathrm{M}$ plants and in its leaves was higher compared to plants NM (mean \pm SE: $0.22 \pm 0.01$ vs $0.17 \pm 0.01 \% \mathrm{DM} ; \mathrm{P}<0.05$ ), and

Table 1. Quantitative performance of maize (mean \pm standard error mean).

\begin{tabular}{lcccc} 
& Control & Mycorrhized & SEM & P \\
DMY (t/ha) & 17.9 & 21.2 & 1.9 & $*$ \\
Grain (t/ha) & 9.5 & 9.6 & 0.1 & $\mathrm{~ns}$ \\
\hline Height (cm) & 203 & 215 & 6 & $\mathrm{~ns}$ \\
Number of plants $/ \mathrm{m}^{2}$ & 4.9 & 5.6 & 0.1 & $*$ \\
\hline Leaves (g) & 85 & 85 & 14 & $\mathrm{~ns}$ \\
Stems (g) & 80 & 76 & 16 & $\mathrm{~ns}$ \\
\hline Ears (g) & 196 & 211 & 22 & $\mathrm{~ns}$ \\
\hline
\end{tabular}

SEM, standard error mean; DMY, dry matter yield; ns, not significant. *P<0.05.

Table 2. Chemical composition of whole plants on dry matter basis (mean \pm standard error mean).

\begin{tabular}{lcccc} 
& Control & Mycorrhized & SEM & P \\
Crude protein (\%) & 7.23 & 7.85 & 0.51 & ns \\
Crude fibre (\%) & 18.66 & 19.04 & 1.53 & ns \\
\hline Neutral detergent fibre (\%) & 55.38 & 56.39 & 1.19 & ns \\
Acid detergent fibre (\%) & 24.38 & 24.53 & 0.75 & ns \\
\hline Acid detergent lignin (\%) & 2.24 & 2.71 & 0.26 & ns \\
Ether extract (\%) & 2.34 & 3.10 & 0.40 & ns \\
\hline Ash (\%) & 6.55 & 8.32 & 1.22 & ns \\
P (\%) & 0.17 & 0.22 & 0.01 & $*$ \\
\hline
\end{tabular}

SEM, standard error mean; ns, not significant; $P$, phosphorus. ${ }^{*} \mathrm{P}<0.05$.

Table 3. Chemical composition of plant leaves on dry matter basis (mean \pm standard error mean).

\begin{tabular}{lcccc} 
& Control & Mycorrhized & SEM & P \\
Crude protein (\%) & 2.54 & 2.73 & 0.52 & ns \\
Crude fibre (\%) & 27.18 & 27.17 & 1.67 & ns \\
\hline Neutral detergent fibre (\%) & 72.26 & 70.89 & 1.82 & ns \\
Acid detergent fibre (\%) & 39.35 & 38.57 & 1.74 & ns \\
\hline Acid detergent lignin (\%) & 2.49 & 2.55 & 0.09 & ns \\
Ether extract (\%) & 1.23 & 1.45 & 0.10 & ns \\
\hline Ash (\%) & 11.65 & 12.79 & 1.36 & ns \\
P (\%) & 0.09 & 0.14 & 0.01 & $*$ \\
\hline
\end{tabular}

SEM, standard error mean; ns, not significant; $\mathrm{P}$, phosphorus. ${ }^{*} \mathrm{P}<0.05$. 
(mean \pm SE: $0.14 \pm 0.01$ vs $0.09 \pm 0.01 \% \mathrm{DM} ; \mathrm{P}<0.05$ ), respectively whole plants and leaves. The content in CF, NDF and ADF $(\mathrm{P}<0.01 ; \mathrm{P}<0.001)$, was higher in the steam of plants NM that to the M (Table 4).

\section{Discussion}

\section{Quantitative parameters}

The main objective of this study was to investigate the effects of AM in maize under low energy inputs. Our results showed that the seeds dressed with spore of Glomus supp. have a $15.5 \%$ more productivity of dry matter per hectare than in NM (Table 1) under low inputs condition. Not difference was found in terms of DM produced for the parts of plant. Micronutrients are needed by the plant in small quantities but are very important for proper growth and development, as they are parts of various enzymes, pigments and other biological molecules essential for plant life (Varma, 2008). Higher productivity observed in $\mathrm{M}$ plot may be due of a significant higher number of plats on $\mathrm{m}^{2}$ than in NM plot. Most probably during the initial period of the germination and growing, the AM helped the seed for uptake the low nutrient present in soil and a major number of seed germinated $(\mathrm{P}<0.05)$. AM, one of the most important rhizosphere compounds that increase the plant strength in biotic and abiotic stress conditions, has the ability to increase the tolerance of plants to high and low humidity conditions (Entry et al., 2002). Different are the micronutrients needed for plant development, most benefits of mycorrhiza have been traced to phosphorus uptake and other elements like zinc also probably play a key role in increase of growth and yield of the plant (Varma, 2008). The arbuscular mycorrhizal symbiosis may alleviate plant responses to drought stress conditions by several mechanisms including water uptake from the soil by AM hyphae. Goicoechea et al. (1997) found that AM was important in maintaining cytokinin levels under drought. The DMY in our trial was lower than to the results obtained in studies under highenergy inputs (Martiniello et al., 2007; Martiniello et al., 2010; Fu et al., 2011), but in agreement with other study (Cox et al., 2009). The industrial corn hybrids are generally very productive, resulting from crosses of genetically selected, but under unfavourable conditions had lower production performance compared to $\mathrm{M}$. Not significant different was found for other quantitative parameters considered.

\section{Qualitative parameters}

The phosphorus content in whole plants and leaves was significantly higher in the M than in NM (Tables 2 and 3). It has been reported that Glomus intraradices significantly increased concentrations of $\mathrm{N}, \mathrm{P}, \mathrm{K}$, $\mathrm{Mg}, \mathrm{Mn}$ and $\mathrm{Zn}$ in grain under drought conditions compared to nonmycorrhizal plants. During the experimental period not supplement irrigation was done and most probably in drought situation the $\mathrm{M}$ plants increased $\mathrm{P}$ concentration than in NM plants. Concentration of heavy metals, e.g. lead, and $\mathrm{P}$ in maize plants generally increases when inoculated with arbuscular mycorrhizal fungi, which suggest significant participation of fungal structures in element accumulation (Sudova and Vosatka, 2007). A previous work established that improved $P$ nutrition at early stages of maize growth is reflected in the final maize yield (Gavito and Miller, 1998). These authors found that in maize shoots $\mathrm{P}$ concentrations increased when a rapid mycorrhizal development was observed. Our trial, inoculated plants took up more total $\mathrm{P}$ and accumulated more $\mathrm{P}$ in the whole plant and leaves than in NM plants, there by suggesting that use of this fungal isolate enhanced the yielding potential of the employed maize cultivar, also when no organic and inorganic fertiliser was applied. Chemical compositions on $\%$ of DM of plant steam are show in Table 4. The content in CF was higher in the steam of plants NM that to the M (mean \pm SE: $29.83 \pm 0.99$ vs $23.41 \pm 0.99 \% \mathrm{DM} ; \mathrm{P}<0.01)$ and also the NDF and $\mathrm{ADF}(\mathrm{P}<0.001)$. The content of CF was $21.5 \%$ less in steam of M plants than in NM. Both CP and $\mathrm{CF}$ have been used widely to compare forage sources being generally negatively correlated and have been, and continue to be, major contributors in ration formulation into the 1980s (National Research Council, 1984). More recently, CF has been de-emphasized while CP warrants attention (National Research Council, 2000). The plant cell contents consist of sugars, starches, soluble proteins, organic acids, and other constituents that are mainly digestible. Schellenbaum et al. (1998) observed that AM symbiosis significantly affected tobacco plants

Table 4. Chemical composition of plant steams on dry matter basis (mean \pm standard error mean).

\begin{tabular}{lcccc} 
& Control & Mycorrhized & SEM & P \\
Crude protein (\%) & 5.85 & 6.23 & 0.85 & ns \\
Crude fibre (\%) & 29.83 & 23.41 & 0.99 & $* *$ \\
\hline Neutral detergent fibre (\%) & 66.26 & 50.78 & 2.32 & $* * *$ \\
Acid detergent fibre (\%) & 38.38 & 28.32 & 1.06 & $* * *$ \\
\hline Acid detergent lignin (\%) & 4.55 & 4.68 & 0.48 & ns \\
Ether extract (\%) & 0.63 & 0.75 & 0.15 & ns \\
\hline Ash (\%) & 6.01 & 4.98 & 0.30 & $*$ \\
P (\%) & 0.07 & 0.08 & 0.01 & ns \\
\hline
\end{tabular}

SEM, standard error mean; ns, not significant; $\mathrm{P}$, phosphorus. ${ }^{*} \mathrm{P}<0.05,{ }^{*} \mathrm{P}<0.01,{ }^{* * *} \mathrm{P}<0.001$.

Table 5. Chemical composition of plant ears on dry matter basis (mean \pm standard error mean).

\begin{tabular}{lcccc} 
& Control & Mycorrhived & SEM & P \\
Crude protein (\%) & 6.35 & 7.23 & 0.85 & ns \\
Crude fibre (\%) & 5.78 & 5.82 & 0.48 & ns \\
\hline Neutral detergent fibre (\%) & 48.16 & 46.90 & 3.19 & ns \\
Acid detergent fibre (\%) & 8.70 & 8.68 & 0.62 & ns \\
\hline Acid detergent lignin (\%) & 1.22 & 1.37 & 0.42 & ns \\
Ether extract (\%) & 4.08 & 3.85 & 0.28 & ns \\
\hline Ash (\%) & 1.59 & 1.72 & 0.18 & ns \\
P (\%) & 0.25 & 0.30 & 0.04 & ns \\
\hline
\end{tabular}

SEM, standard error mean; ns, not significant; P, phosphorus.

Table 6. Chemical composition of maize grains on dry matter basis (mean \pm standard error mean).

\begin{tabular}{lcccc} 
& Control & Mycorrhived & SEM & P \\
Crude protein (\%) & 7.85 & 8.20 & 0.55 & ns \\
Crude fibre (\%) & 3.10 & 3.47 & 0.42 & ns \\
\hline Neutral detergent fibre (\%) & 28.21 & 26.36 & 2.83 & ns \\
Acid detergent fibre (\%) & 4.61 & 5.37 & 0.38 & ns \\
\hline Acid detergent lignin (\%) & 1.33 & 1.32 & 0.08 & ns \\
Ether extract (\%) & 6.11 & 6.45 & 0.63 & ns \\
\hline Ash (\%) & 2.09 & 2.20 & 0.16 & ns \\
P (\%) & 0.43 & 0.46 & 0.05 & ns \\
\hline
\end{tabular}

SEM, standard error mean; ns, not significant; P, phosphorus. 
during drought in terms of soluble carbohydrate accumulation and partitioning. Their AM plants accumulated less glucose and fructose in leaves and roots than NM plants in drought conditions. Similar findings were reported for rose and pepper after drought (Davies et al., 1993). Schellenbaum et al. (1998) suggested that the fungus is a strong competitor for root-allocated carbon under conditions limiting photosynthesis and it is also possible that higher sugar concentrations in NM than in M tissues result when NM plants suffer greater drought strain. Most probably the effect of symbiosis between root and plant have been a positive effect during the summer period on the M plants, and also on the quality. The fibre content in steam in our study was lower than to the results obtained in study under high-energy inputs (Li et al., 2010), but in agreement with Boona et al. (2012). Not different was found for over parameter considered in steam and also for ear and grain quality between the treatments (Tables 5 and 6 ).

\section{Conclusions}

The development of sustainable agricultural systems with low-input of mineral fertilizers and chemical pesticides is an issue that is gaining ground. In Europe, the EU stimulates sustainability in a wide range of fields including agriculture. Mycorrhizal fungi are key organisms that can be beneficial in the development of strong and healthy crops with reasonable yield in low-input systems. Management of mycorrhizae in field conditions through agricultural practices could reduce fertiliser application required for most economical yield. These preliminary results support the hypothesis that plants inoculated with commercial AM inoculum show high yield under low energy inputs, with a greater concentration of $\mathrm{P}$ in plants and in leaves and a lower fibre content and its fractions in stems. However, further studies are needed to monitor the vitality of mycorrhizal roots and to study the relationship between vegetative stages, reproductive stages and rainfall.

\section{References}

AOAC (Association of Official Analytical Chemist), 1990. Official methods of analysis, 15th ed. AOAC, Artington, VA, USA.

Augé RM, 2001. Water relations, drought and vesicular-arbuscular mycorrhizal symbiosis. Mycorrhiza 11:3-42.

Boona EJMC, Struika PC, Engelsa FM, Conec JW, 2012. Stem characteristics of two forage maize (Zea mays L.) cultivars varying in whole plant digestibility. IV. Changes during the growing season in anatomy and chemical composition in relation to fermentation characteristics of a lower internode. NJAS Wageningen J. Life Sci. 59:1323.

Cox WJ, Cherney JH, Hanchar JH, 2009. Zone tillage depth affects yield and economics of corn silage production. Agron. J. 101:1093-8.

Davies FT, Potter JR, Linderman RG, 1993. Drought resistance of mycorrhizal pepper plants independent of leaf P-concentration response in gas exchange and water relations. Physiol. Plant. 87:45-53.

Entry JA, Rygiewicz PT, Watrud LS, Donelly PK, 2002. Influence of adverse soil conditions on the formation and function of arbuscular mycorrhizas. Adv. Environ. Res. 7:123-38.
Fu F, Guo C, Tang Q, Liu J, Li W, 2011. Growth dynamics and optimal harvesting stage of two forage maize varieties. Agri. Sci. China 10:220-7.

Gavito ME, Miller MH, 1998. Early phosphorus nutrition, mycorrhizae development, dry matter partitioning and yield of maize. Plant Soil 199:177-86

Goicoechea N, Antolin MC, Sanchez-Diaz M, 1997. Influence of arbuscular mycorrhiza and rhizobium on nutrient content and water relations in drought stressed alfalfa. Plant Soil 192:261-8.

Gosling P, Hodge A, Goodlass G, Bending GD, 2006. Arbuscular mycorrhizal fungi and organic farming. Agric. Ecosyst. Environ. 113:17-35.

Li H, Li L, Wegenastb T, Longinb, Xiaowei Xua CF, Melchingerb AE, Chen S, 2010. Effect of N supply on stalk quality in maize hybrids. Field Crops Res. 118:208-14.

Liu A, Hamel C, Hamilton R I, Ma BL, Smith DL, 2000. Acquisition of Cu, $\mathrm{Zn}, \mathrm{Mn}$ and Fe by mycorrhizal maize (Zea mays L.) grown in soil at different $P$ and micronutrient levels. Mycorrhiza 9:331-6.

Martiniello P, Gesualdo G, Sabia E, Terzano GM, Pacelli C, Berardo N, 2007. Intensive rainfed and irrigated forage crop production for Mediterranean Italian Buffalo feeding. Ital. J. Anim. Sci. 6:1226-9.

Martiniello P, Annicchiarico G, Sabia E, Terzano GM, Odoardi M, Pintus B, Pacelli C, Rossi E, Concetti S, 2010. Utilization of Buffalo's manure for forage production in sustainable agriculture. Rev. Vet. 21:817-9.

Menèndez AB, Scervino JM, Godeas AM, 2001. Arbuscular mycorrhizal populations associated with natural and cultivated vegetation on a site of Buenos Aires province, Argentina. Bio. Fert. Soils. 33:373-81.

National Research Council, 1984. Nutrient requirements of beef cattle, 6th ed. Natl. Acad. Press, Washington, DC.

National Research Council, 2000. Nutrient requirements of beef cattle, 7th ed. Natl. Acad. Press, Washington, DC.

Rilling MC, 2004. Arbuscular mycorrhizae and terrestrial ecosystem processes. Ecol. Lett. 7:740-54.

Sabia E, Claps S, Napolitano F, Annicchiarico G, Bruno A, Francaviglia $\mathrm{R}$, Sepe L, Aleandri R, 2015. In vivo digestibility of two different forage species inoculated with arbuscular mycorrhiza in Mediterranean red goats. Small Ruminant Res. 123:83-7.

Schellenbaum L, Muller J, Boller T, Wiemken A, Schüepp H, 1998. Effects of drought on non-mycorrhizal and mycorrhizal maize: changes in the pools of non-structural carbohydrates, in the activities of invertase and trehalase, and in the pools of amino acids and imino acids. New Phytol. 138:59-66.

Smith SE, Reed DJ, 1997. Mycorrhizal symbiosis, 2nd ed. Academic Press, London, UK, p 589.

Stelluti M, 2009. Caratterizzazione agroclimatica della basilicata con la produzione di carte tematiche ottenute dallo studio della variabilità spaziale e l'interpolazione dei dati climatici secondo le moderne tecniche di elaborazione geostatistiche. Available from: åhttp://editssa.ssabasilicata.it/opencms/CANALI_TEMATICV/Agrom eteorologia/File_allegati/Pluviometria_della_Basilicata.pdf

Sudova R, Vosatka $\bar{M}, 2007$. Difference in the effects of three arbuscular mycorrhizal fungal strains on $\mathrm{P}$ and $\mathrm{Pb}$ accumulation by maize plants. Plant Soil 296:77-83.

Van Soest PJ, Robertson JB, Lewis BA, 1991. Methods for dietary fiber, neutral detergent fiber, and nonstarch polysaccharides in relation to animal nutrition. J. Dairy Sci. 74:3583-97.

Varma A, 2008. Mycorrhizal, 3rd ed. Springer-Verlag, Berlin-Heidelberg, Germany. 